\title{
COMPONENT COMPOSITION OF ESSENTIAL OIL SHOOTS AND LEAVES OF LAURUS NOBILIS L. UKRAINIAN ORIGIAN
}

\author{
Olga Khvorost, Irina Posohova, Yuliia Fedchenkova, Katerina Skrebtsova
}

The aim of our work was to carry out a comparative analysis of the essential oils of shoots and leaves of Laurus nobilis L. Ukrainian flora and to determine the prospects for their use in pharmacy.

Materials and methods. Raw materials for obtaining essential oil (shoots and leaves) of Laurus nobilis L. were harvested in November 2017 in the southern regions of Ukraine.

By the method of chromatography-mass spectrometry using an Agilent Technology 6890N chromatograph, the component composition of 4 samples of essential oil of Laurus nobilis L. raw material was investigated and identified. The composition of the essential oil was identified by comparing the results with the data from the NIsT 02 mass spectra library (more than 174,000 substances).

Results. Thus, in the studied series of the essential oil of the shoots, a similarity was observed both in the set of components and in the relative content of a number of individual compounds and compounds of structurally related groups. The content in these samples was dominated by 1,8-cineole (19.63\% of the amount and $12.93 \%$ of the amount, respectively), $\alpha$-terpinyl acetate (16.22\% of the amount and $16.03 \%$ of the amount, respectively).

In contrast to the series of the essential oil of the shoots, the component composition of the essential oil of the leaves of the two series was significantly different. In both studied series, only 3 compounds were identified that are common these are aromatic compounds methyleugenol, trans-methylisoevgenol, and the sequiterpenoid caryophyllene oxide.

Conclusions. Thus, a comparative analysis of the component composition of biologically active substances in the essential oils of shoots and leaves of the Laurus nobilis L. Ukrainian harvest showed the prospects for further pharmacognostic research of this plant as a source of medicinal raw materials

Keywords: Laurus nobilis L., shoots, leaves, essential oil, 1,8-cineole, $\alpha$-terpinyl acetate, spatulenol, methyleugenol

How to cite:

Khvorost, O., Posohova, I., Fedchenkova, Yu., Skrebtsova, K. (2021). Component composition of essential oil shoots and leaves of Laurus nobilis L. Ukrainian origian. ScienceRise: Pharmaceutical Science, 4 (32), 50-58. doi: http://doi.org/10.15587/2519-4852.2021.239335

(C) The Author(s) 2021

This is an open access article under the Creative Commons CC BY license hydrate

\section{Introduction}

The search for new medicinal plants and expanding the range of herbal medicines is one of the top priorities of the pharmaceutical industry of any country, Ukraine is no exception. Attention is drawn to those plants that have long been used in folk medicine, are widespread in a particular area, and this is accompanied by an insufficient degree of study. Such a representative of the flora is Laurus nobilis L. of the family Lauraceae [1]. Laurus leaves were used as a seasoning for a huge number of dishes, but its value in a large number of useful properties [2, 3].

Analysis of literature data and previous chemical studies have shown the presence in the raw material of Laurus nobilis L. fatty acids, amino acids, a number of compounds of phenolic nature [4], including tannins and coumarins [5], bitters, essential oils with a wide range of biological activity $[6,7]$.

Spicy-aromatic plant with healing properties as a valuable crop is grown in many countries. The information of a number of foreign literature sources devoted to the composition of the essential oil of raw materials of this plant of different places of growth is analyzed. Thus, in the essential oil of raw Laurus nobilis L. from Turkey (leaves) [5], Iran (leaves) [8], Bulgaria (leaves, shoots, fruits) [9] and Montenegro (leaves, shoots, fruits) [10] common and main components were 1,8-cineole, sabinene and $\alpha$-terpinyl acetate, but in the leaves of Laurus nobilis L. from Southern Italy the content of $\alpha$-terpinyl acetate was negligible [11]. The significant content of linalool is characteristic of the essential oil of Laurus nobilis L. leaves from Southern Italy, Bulgaria and Montenegro. The highest content of methyleugenol was found in the essential oil of Laurus nobilis L. from Iran and Bulgaria. The essential oil of Laurus nobilis L. from Turkey, Bulgaria, and Montenegro contains a significant amount of $\alpha$-pinene, and $\beta$-pinene was the main component only for the essential oil of raw materials from Turkey and Montenegro. Significant content of 4-terpineol is characteristic of raw materials from Turkey and Bulgaria, and raw materials Laurus nobilis L. Iran contains significant amounts of trans-sabinene hydrate and eugenol. According to literature sources, the composition of the essential oil depends on the place of growth of the plant, the method of production and method of storage. 
The raw materials of the plant have long been widely used in folk medicine as a natural antibiotic, antiseptic and anti-inflammatory agent. Extracts from raw materials are relevant for people suffering from respiratory diseases, for the prevention and treatment of tuberculosis, as a protector against colds and viruses. In addition, volatile compounds are able to soothe the baby before bedtime, a decoction of the leaves of Laurus nobilis L. is used for skin manifestations of diaper dermatitis in infants, in adolescence - washing treats acne. Regular washing of hair with this tool gets rid of dandruff. The decoction is widely used in diseases of the oral cavity, it stops bleeding gums, heals small wounds, ulcers. Laurus nobilis L. is recommended for arthritis, rheumatism and gout as an antiinflammatory, analgesic and anti-edematous. It is used in hypertension to normalize blood pressure, antispasmodic properties of the plant relieve pain in the intestine. Decoction of the leaves of Laurus nobilis L. helps to strengthen the immune system. Foot baths with leaves of Laurus nobilis L. will get rid of sweating feet, rubbing with oil with an extract of Laurus nobilis L. will help with exacerbations of osteochondrosis. In the world scientific literature there is much evidence of a wide range of pharmacological activity of the essential oil Laurus nobilis L. Scientists from different countries have confirmed antifun- gal and bactericidal activity [12], a beneficial effect on the digestive system [13]. In the literature there is information about the study of essential oil of Laurus nobilis L. leaves as a remedy against nematodes [14], there is information about cytotoxic [15] and antioxidant effects [4, 16, 17], extracts from raw Laurus nobilis L. showed in vitro antidiabetic activity [3]. Raw materials are also widely used in the manufacture of medicines, perfumes and cosmetics as a flavouring and as ansecticide [6, 18, 19].

At the same time, the raw material of Laurus nobilis L. in Ukraine is still not official.

The plant is used as an auxiliary in medicines and cosmetics, but, given the chemical composition, a wide range of biological activity, further study of plant raw materials as a source for the creation of medicines is relevant.

The aim of the study was to conduct a comparative analysis of essential oils of shoots and leaves of Laurus nobilis L. of Ukrainian flora and to determine the prospects of their use in pharmacy.

\section{Planning (methodology) of the research}

The stages of research of raw materials Laurus nobilis L. are shown in Fig. 1.

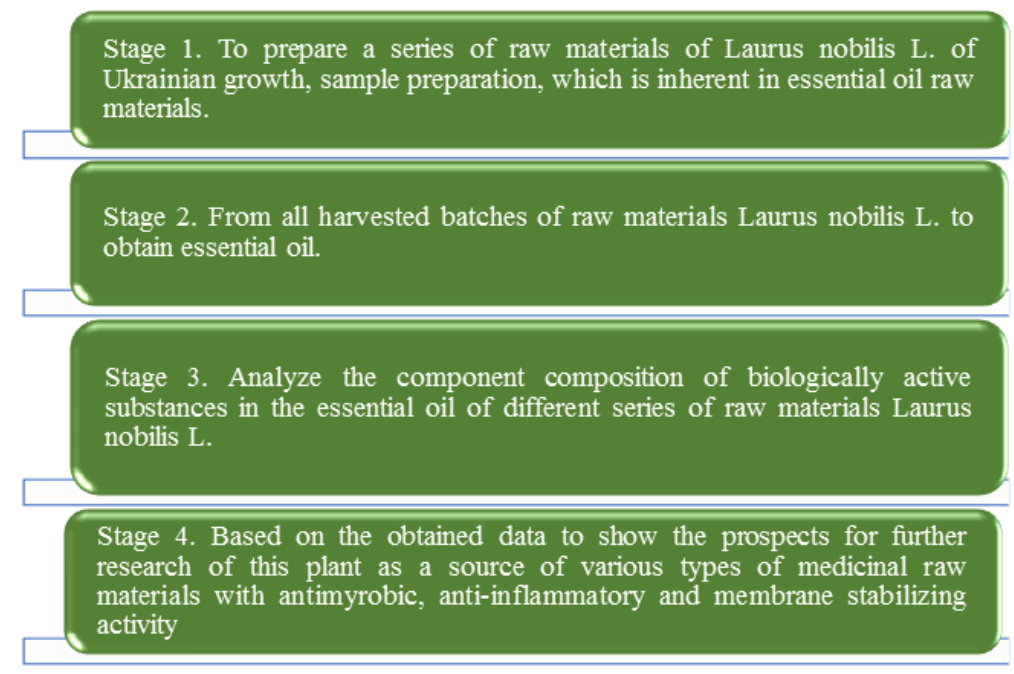

Fig. 1. Stages of the study of the component composition of the essential oil of shoots and leaves of Laurus nobilis L.

\section{Materials and methods}

The object of the study was the essential oil of 4 samples of raw materials Laurus nobilis L. of Ukrainian origin. Shoots (leafless, 1-2 years of vegetation) and leaves of series 1-2 Laurus nobilis L. were harvested in November 2017 in the southern regions of Ukraine.

Confirmation of the systematic species authenticity was carried out by the associate professor of the Department of Botany of NUPh Rudenko V.P.

A portion $(60.0 \mathrm{~g})$ of the crushed raw material (leaves or shoots of Laurus nobilis L.) was transferred into a $1 \mathrm{~L}$ flask, $300 \mathrm{ml}$ of water was added, and the flask was connected to a vapour tube. Filled with water graduated and drain tubes through the tap with a rubber tube with a funnel at the end. Heated and boiled at an intensity at which the flow rate of the distillate was 60-65 drops per minute. After 5 minutes before the end of the distilla- tion, the tap was opened, gradually lowering the distillate so that the essential oil occupied the graduated part of the receiver tube, measuring the volume of essential oil. The distillation time was 2 hours.

The yield of essential oil $(\mathrm{X}, \%)$ in terms of absolute dry matter was calculated by the formula:

$$
x=\frac{V \cdot 100 \cdot 100}{m \cdot(100 \cdot W)},
$$

where $\mathrm{V}$ - volume of essential oil, $\mathrm{ml} ; \mathrm{m}$ - mass of raw materials, g; W - weight loss during drying of raw materials, $\%$.

Essential oils were easily mobile liquids with a characteristic odor, well soluble in $95 \%$ ethanol, chloroform.

Analysis of the component essential oils of shoots, leaves of Laurus nobilis L. was determined 
using the chromato-mass spectrometric method using a chromatograph Agilent Technology 6890N, equipped with a mass-selective detector 5973N. Quartz column, capillary HP-5MS with a length of $30 \mathrm{~m}$ and an inner diameter of $0.25 \mathrm{~mm}$, filled with $5 \%$ phenylmethylsiloxane. Previously, the column temperature was programmed: the initial column temperature was 8 min at $50{ }^{\circ} \mathrm{C}$, and then gradually increased to the final $-220{ }^{\circ} \mathrm{C}$. Acceleration rate $4 \mathrm{deg} / \mathrm{min}$. Carrier gas helium; flow rate $1 \mathrm{ml} / \mathrm{min}$. The duration of acceleration is 1 hour. The sample volume was $0.5 \mu \mathrm{l}$ at a flow factor of 1:50 and a pressure at the inlet of the column of $40 \mathrm{kPa}$. The scan was performed in the range of 38 300 a.e.m. Recording time 0.5 s.

The component composition of the essential oil was identified by comparing the results obtained by chromatography of the mass spectra of chemicals includ- ed in the test mixture with the data of the library of mass spectra NIsT 02 (more than 174,000 substances) [20].

\section{Results}

The essential oil of two samples of shoots of different growth places was studied, because it is known from literature sources that shoots, in addition to leaves and fruits, are also a source of essential oil. Thus, the shoots of series 1 contained $0.85 \pm 0.05 \%$, the shoots of series $2-0.91 \pm 0.04$ $\%$ of essential oil in terms of dry raw materials.

The study revealed that the component composition of the essential oil of both studied series of shoots is similar in both the set of components and the relative content of a number of individual compounds and compounds of structurally related groups. Gas chromatograms of the components of the essential oil of 2 series of shoots of Laurus nobilis L. are shown in Fig. 2.

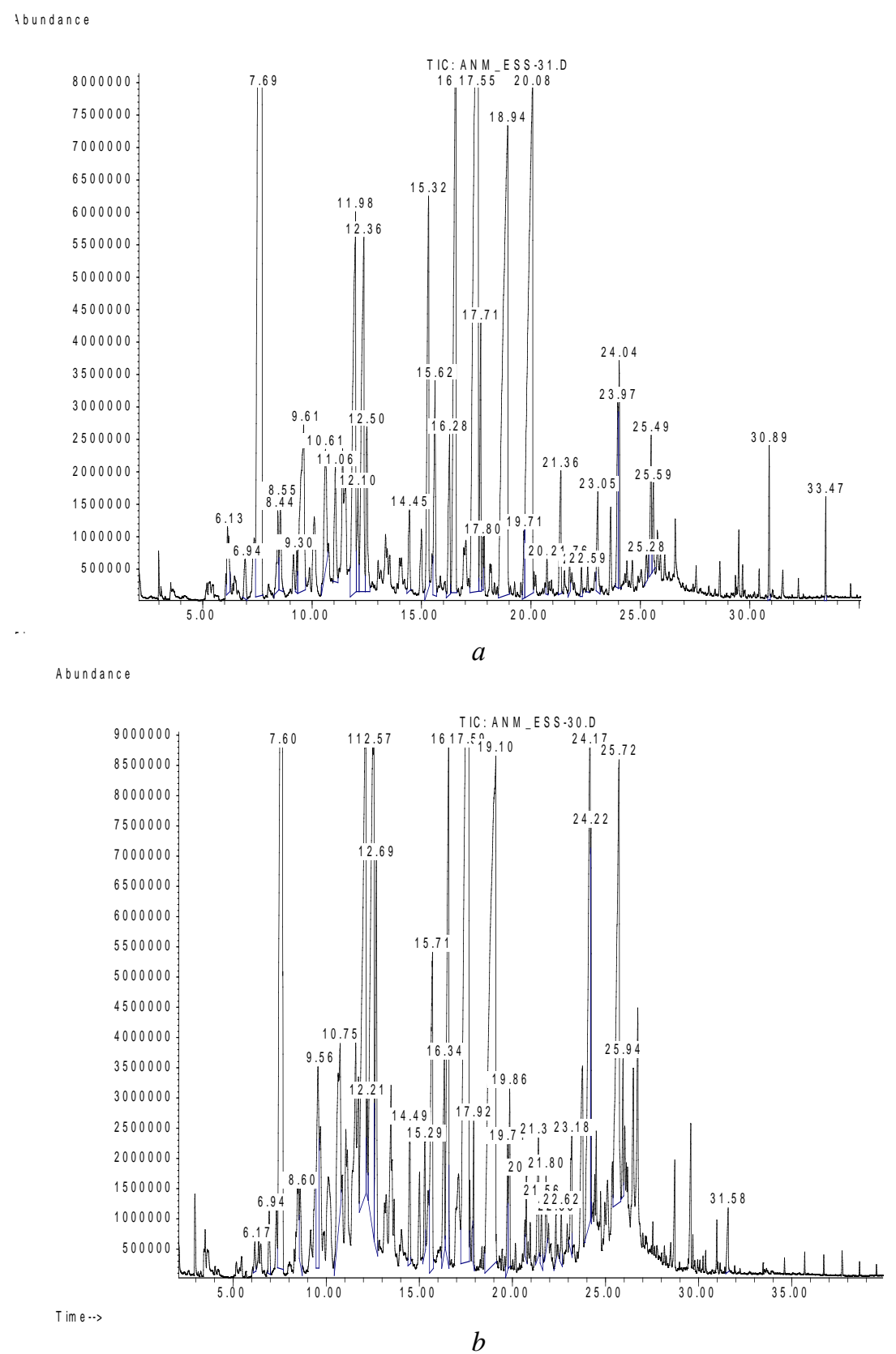

Fig. 2. Gas chromatograms of the components of the essential oil of the shoots of Laurus nobilis L.: $a$-series $1 ; b$-series 2 
It was found that in the shoots of Laurus nobilis L. series 1 were found at least 36 essential oil (Table 1), and in the shoots of series 2 - at least 30 components.
10 compounds (of which 1 is unidentified) are characteristic only of the essential oil of shoots of series 1 , and $4-$ only in the essential oil of shoots of series 2 .

Table 1

Component composition of essential oil of 2 series of shoots of Laurus nobilis L.

\begin{tabular}{|c|c|c|c|c|c|}
\hline \multirow{3}{*}{ No. } & \multirow{3}{*}{ Compound name } & \multicolumn{4}{|c|}{ Shoots } \\
\hline & & \multicolumn{2}{|c|}{ series 1} & \multicolumn{2}{|c|}{ series 2} \\
\hline & & $\begin{array}{c}\text { Retention time, } \\
\text { min }\end{array}$ & $\%$ of the amount & $\begin{array}{c}\text { Retention time, } \\
\text { min }\end{array}$ & \% від суми \\
\hline 1 & Sabinene & 6.13 & 0.75 & 6.16 & 0.20 \\
\hline 2 & $\alpha$-Phellandrene & 6.94 & 0.42 & 6.94 & 0.41 \\
\hline 3 & 1,8-Cineole & 7.69 & 19.63 & 7.59 & 12.93 \\
\hline 4 & $\gamma$-Terpinene & 8.43 & 0.68 & - & - \\
\hline 5 & trans-Sabinene hydrate & 8.54 & 0.78 & 8.60 & 0.64 \\
\hline 6 & cis-Sabinene hydrate & 9.30 & 0.27 & 9.55 & 2.07 \\
\hline 7 & $\beta$-Phenylethyl alcohol & 9.60 & 3.55 & - & - \\
\hline 8 & Pinocarveol & 10.60 & 1.62 & 10.74 & 3.19 \\
\hline 9 & Pinocarvone & 11.06 & 1.14 & - & - \\
\hline 10 & Terpinene-4-ol & 11.98 & 5.73 & 12.12 & 8.58 \\
\hline 11 & Myrtenal & 12.09 & 0.85 & 12.20 & 0.50 \\
\hline 12 & $\alpha$-Terpineol & 12.36 & 4.84 & 12.56 & 9.00 \\
\hline 13 & Myrtenol & 12.49 & 1.41 & 12.68 & 3.14 \\
\hline 14 & Dodecanone-2 & 14.44 & 0.68 & 14.49 & 0.96 \\
\hline 15 & Bornylacetate & 15.32 & 3.69 & 15.29 & 0.71 \\
\hline 16 & Undecanone-2 & 15.61 & 1.76 & 15.71 & 3.35 \\
\hline 17 & Terpinen-4-ol acetate & 16.27 & 1.36 & 16.34 & 1.67 \\
\hline 18 & $\alpha$-Terpinyl acetate & 17.54 & 16.22 & 17.58 & 16.03 \\
\hline 19 & 3-Phenyl-1-propyl acetate & 17.70 & 1.68 & - & - \\
\hline 20 & Geranyl acetate & 17.79 & 0.24 & - & - \\
\hline 21 & trans-Methylisoeugenol & 18.94 & 12.06 & - & - \\
\hline 22 & Methyleugenol & - & - & 19.10 & 15.82 \\
\hline 23 & $\beta$-Caryophyllene & 19.71 & 0.49 & 19.73 & 0.76 \\
\hline 24 & Cinnamyl acetate & 20.07 & 12.24 & 19.85 & 1.08 \\
\hline 25 & Tetradecanon-2 & 20.73 & 0.20 & 20.74 & 0.38 \\
\hline 26 & trans-methylisoeugenol & 21.36 & 0.99 & 21.39 & 0.89 \\
\hline 27 & $\alpha$-Selinene & - & - & 21.55 & 0.43 \\
\hline 28 & Pentadecanon-2 & 21.76 & 0.20 & 21.80 & 0.43 \\
\hline 29 & $\alpha$-Amorphene & 22.30 & 0.18 & 22.33 & 0.22 \\
\hline 30 & $\delta$-Cadinene & 22.59 & 0.15 & 22.62 & 0.32 \\
\hline 31 & Elemicin & 23.05 & 0.81 & 23.18 & 0.93 \\
\hline 32 & Spatulenol & 23.96 & 1.55 & 24.16 & 6.13 \\
\hline 33 & Caryophyllene oxide & 24.03 & 1.09 & 24.21 & 1.35 \\
\hline 34 & Unidentified compound & 25.27 & 0.21 & - & - \\
\hline 35 & $\gamma$-betulenol & 25.49 & 0.94 & 25.71 & 6.72 \\
\hline 36 & trans-isoelemicin & 25.59 & 0.58 & - & - \\
\hline 37 & Eudesmol & - & - & 25.94 & 0.73 \\
\hline 38 & Nonadecan & 30.88 & 0.62 & $\begin{array}{lll}- \\
\end{array}$ & - \\
\hline 39 & Palmitic acid & - & - & 31.58 & 0.43 \\
\hline 40 & Heneicosane & 33.46 & 0.39 & - & - \\
\hline
\end{tabular}

Only for the essential oil of shoots of series 1 is characterized by the presence of $\gamma$-terpinene, $\beta$ phenylethyl alcohol, pinocarvone, 3-phenyl-1-propyl acetate, geranyl acetate, trans-isoelemicin, nonadecane and heneicosane. The presence of methyleugenol, $\alpha$ selinen, eudesmol and palmitic acid was characteristic only for the essential oil of shoots of series 2 .

The content in these samples was dominated by 1,8-cineole $(19.63 \%$ of the amount and $12.93 \%$ of the amount, respectively), $\alpha$-terpinyl acetate (16.22\% of the amount and $16.03 \%$ of the amount, respectively). A high content of methyleugenol (15.82\% of the amount) was determined for the essential oil of Laurus nobilis L. series 2 shoots. Cinnamyl acetate and transmethylisoeugenol in significant quantities $(12.24 \%$ of the amount and $12.06 \%$ of the amount, respectively) were found in 1 series. The essential oil of shoots of series 2 has a significant content of $\alpha$-terpineol $(9.0 \%$ of the amount), terpinene-4-ol (8.58\% of the amount) and $\gamma$-betulenol (6.72\% of the amount).

The component composition of essential oil compounds of 2 series of Laurus nobilis L. leaves was also 
studied (Fig. 3). The component composition of the compounds of the essential oil of the leaves of Laurus nobilis L. series 1 is shown in Table 2, and series 2 in Table 3.

Abundance

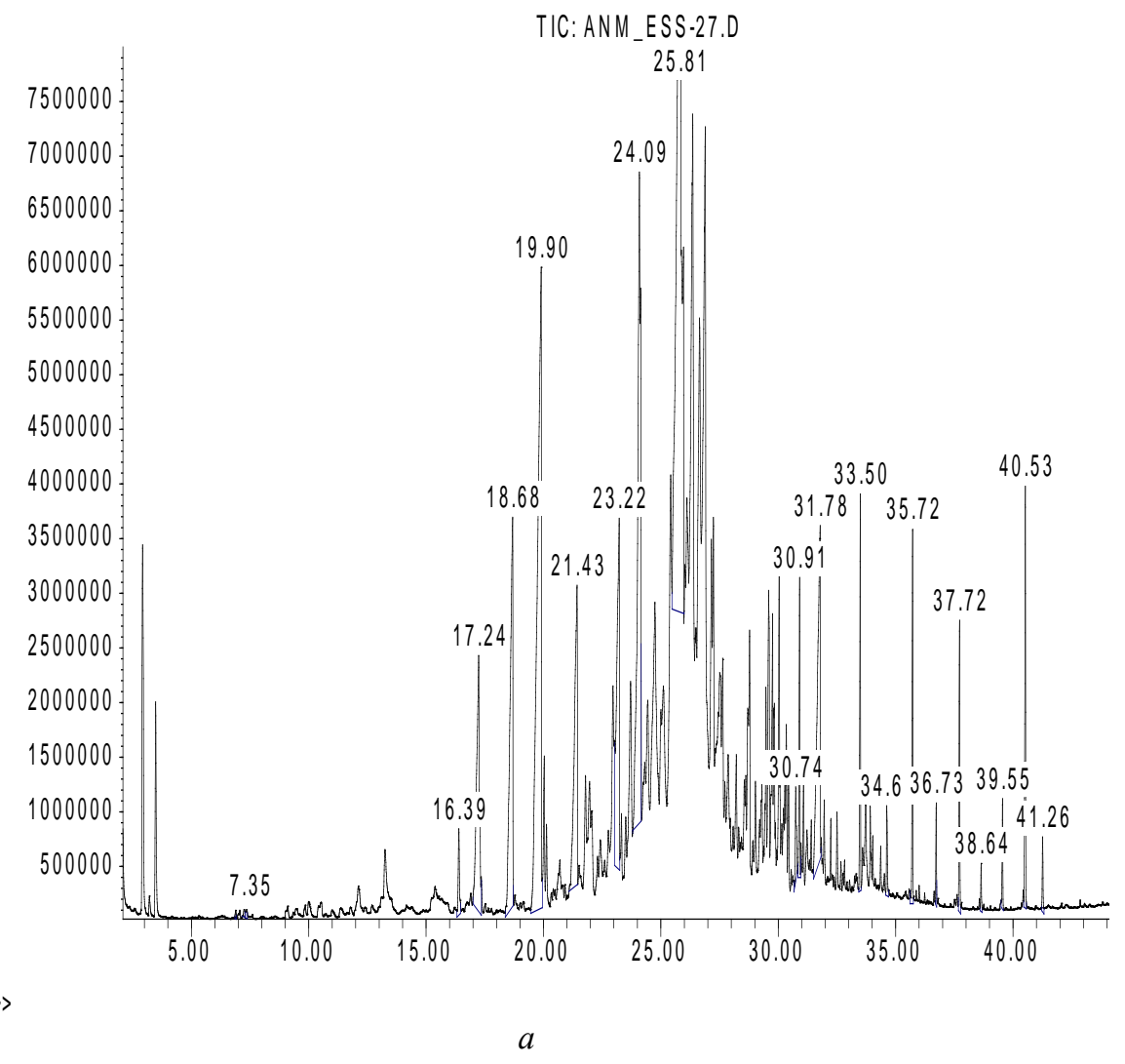

Abundance

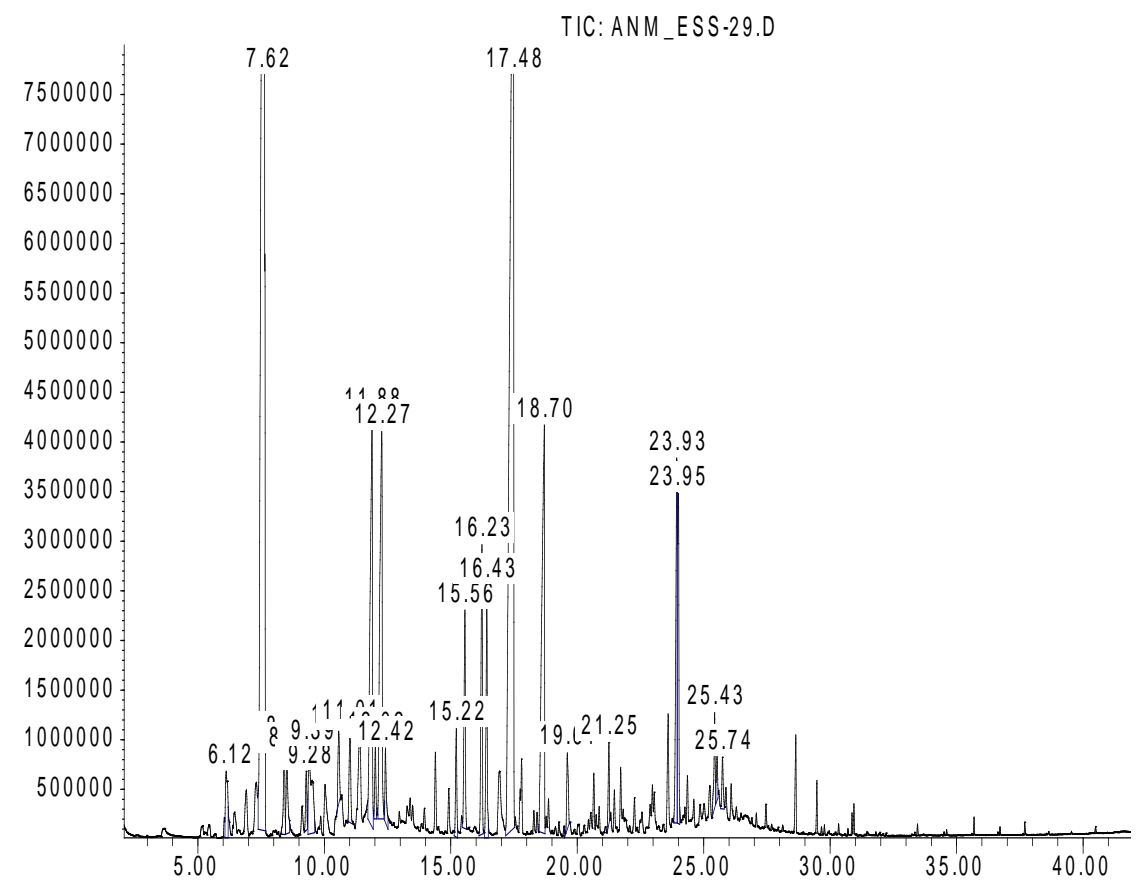

Time-:>

$b$

Fig. 3. Gas chromatogram of compounds of essential oil of leaves of Laurus nobilis L.: $a-\operatorname{series~} 1 ; b-\operatorname{series} 2$ 
Thus, the leaves of series 1 contained $2.15 \pm 0.09 \%$, the leaves of series $2-2.75 \pm 0.09 \%$ of essential oil in terms of dry raw materials.

In contrast to the series of shoots of Laurus nobilis L., for which there were a total of 28 compounds distilled with water vapour (Table 1), in the series of essential oils of the leaves of this plant there was a different pattern (Tables 2, 3). The composition of the compounds of the essential oil of the leaves of different series differed significantly in both the set of components and the relative content of structurally related groups of compounds.

The leaves in comparison with the shoots are more ontogenetically plastic, vulnerable to changes in a number of environmental factors, part of the plant. And such a difference in component composition is proof of this. And this fact, by the way, can explain a fairly close qualitative composition of the essential oil of shoots from two fairly close to the place of harvesting and such a discrepancy between this figure in the leaf.

In both series, only 3 compounds were found that are common - aromatic compounds methyleugenol (7.14\% of the amount in the leaves of series 1 and $7.57 \%$ of the amount in the sheet of series 2), trans-methylisoeugenol (content was $5.7 \%$ of amounts in the essential oil of leaves of series 1 , which is almost 9 times higher than in the essential oil of leaves of series $2-0.65 \%$ of the amount) and sequiterpenoid caryophyllene oxide (4 times difference: in series $1-13.09 \%$ of the amount against $3,53 \%$ of the amount in series 2 ).

Table 2

Component composition of essential oil of leaves of Laurus nobilis L. series 1

\begin{tabular}{|c|l|c|c|}
\hline No & \multicolumn{1}{|c|}{$\begin{array}{c}\text { The name of the } \\
\text { compound }\end{array}$} & $\begin{array}{c}\text { Retention } \\
\text { time, min. }\end{array}$ & $\begin{array}{c}\text { \% of the } \\
\text { amount }\end{array}$ \\
\hline 1 & $\begin{array}{l}\text { cis-2,6-Dimethyl-1,3,5,7- } \\
\text { octatriene }\end{array}$ & 6.88 & 0.05 \\
\hline 2 & Allylbenzene & 7.25 & 0.09 \\
\hline 3 & $\begin{array}{l}\text { Trans-2,6-Dimethyl- } \\
1,3,5,7-\text {-octatriene }\end{array}$ & 7.35 & 0.12 \\
\hline 4 & Eugenol & 17.23 & 5.03 \\
\hline 5 & Methyleugenol & 18.68 & 7.14 \\
\hline 6 & Cinnamyl acetate & 19.90 & 16.92 \\
\hline 7 & trans-methylisoeugenol & 21.43 & 5.70 \\
\hline 8 & Elemicin & 23.22 & 6.23 \\
\hline 9 & Caryophyllene oxide & 24.08 & 13.09 \\
\hline 10 & $\begin{array}{l}\text { Caryophylla-4(12),8(13)- } \\
\text { diene-5-o }\end{array}$ & 25.80 & 26.58 \\
\hline 11 & Farnesylacetone & 30.74 & 0.67 \\
\hline 12 & Nonadecan & 30.91 & 1.68 \\
\hline 13 & Palmitic acid & 31.78 & 6.56 \\
\hline 14 & Heneicosane & 33.49 & 2.14 \\
\hline 15 & Docosane & 34.62 & 0.55 \\
\hline 16 & Tricosane & 35.72 & 2.01 \\
\hline 17 & Tetracosane & 36.72 & 0.45 \\
\hline 18 & Pentacosane & 37.72 & 1.51 \\
\hline 19 & Hexacosane & 38.64 & 0.24 \\
\hline 20 & Heptacosane & 40.52 & 0.54 \\
\hline 21 & Squalene & 41.26 & 0.39 \\
\hline 22 & Nonacosane & & \\
\hline
\end{tabular}

In series 1 of the essential oil of the leaves of Laurus nobilis L. identified 22 substances, of which dominated by compounds of the caryophyllene type caryophylla-4(12),8(13)-dien-5-ol $\quad(26.58 \%$ of the amount) and caryophyllene oxide (13, $09 \%$ of the amount), as well as a complex ester of cinnamic alcohol cinnamyl acetate (16.92\% of the amount). Hydrocarbons are represented by a variety of compounds - groups of normal paraffins (alkanes) from nonadecane to nonacosane (C19-C29), the total content of which was equal to $7.84 \%$ of the amount, as well as unsaturated hydrocarbons of triterpene origin squalene $(2.31 \%$ of the amount), for which is characterized by anticancer, antimicrobial, fungicidal and immunostimulatory activity.

Table 3

Component composition of essential oil of leaves of Laurus nobilis L. series 2

\begin{tabular}{|l|l|c|c|}
\hline $\begin{array}{c}\mathrm{N} \\
\text { o. }\end{array}$ & \multicolumn{1}{|c|}{$\begin{array}{c}\text { The name of the com- } \\
\text { pound }\end{array}$} & $\begin{array}{c}\text { Retention } \\
\text { time, min. }\end{array}$ & $\begin{array}{c}\text { \% of the } \\
\text { amount }\end{array}$ \\
\hline 1 & Sabinene & 6.11 & 1.00 \\
\hline 2 & 1,8 -Cineole & 7.62 & 29.78 \\
\hline 3 & $\gamma$-Terpinene & 8.41 & 0.94 \\
\hline 4 & Trans-Sabinene hydrate & 8.51 & 0.98 \\
\hline 5 & Terpinolene & 9.28 & 0.54 \\
\hline 6 & Cis-Sabinene hydrate & 9.38 & 2.17 \\
\hline 7 & Pinocarveol & 10.56 & 0.76 \\
\hline 8 & Pinocarvone & 11.01 & 1.08 \\
\hline 9 & Terpinene-4-ol & 11.88 & 6.38 \\
\hline 10 & Myrtenal & 12.02 & 0.64 \\
\hline 11 & $\alpha$-Terpineol & 12.27 & 6.34 \\
\hline 12 & Myrtenol & 12.41 & 0.72 \\
\hline 13 & Bornylacetate & 15.21 & 0.96 \\
\hline 14 & Undecanon-2 & 15.55 & 2.18 \\
\hline 15 & Terpinen-4-ol acetate & 16.22 & 2.84 \\
\hline 16 & $\alpha$-Terpinyl acetate & 17.47 & 25.02 \\
\hline 17 & Methyleugenol & 18.69 & 7.57 \\
\hline 18 & $\beta$-Caryophyllene & 19.60 & 0.84 \\
\hline 19 & Trans-Methylisoeugenol & 21.25 & 0.65 \\
\hline 20 & Spatulenol & 23.93 & 3.29 \\
\hline 21 & Caryophyllene oxide & 23.95 & 3.53 \\
\hline 22 & $\begin{array}{l}\text { Caryophylla- } \\
4(12), 8(13)-d i e n e-5-o l\end{array}$ & 25.43 & 0.90 \\
\hline 23 & Trans-isoelemicin & 25.52 & 0.39 \\
\hline 24 & $\beta$-Eudesmol & 25.74 & 0.50 \\
\hline & & & \\
\hline
\end{tabular}

Table 3 shows that in the essential oil of the leaves of series 2 Laurus nobilis L. determined the presence of at least 24 substances. Dominated by the content of $\alpha$-terpinyl acetate ( $25.02 \%$ of the amount), 1,8-cineole (29.78\% of the amount).

Of the 36 compounds of the essential oil of shoots of the 1 st series, only 2 are available in the essential oil of the leaves of the 1st series: cinnamyl acetate (12.24\% of the amount and $16.92 \%$ of the amount, respectively) and caryophyllene oxide (1.09\% of the amount and $13.09 \%$ of amounts, respectively). Of the 30 compounds of the essential oil of shoots 2 series 19 are common to the essential oil of the leaves of the same series with a predominance of 1,8 -cineole $(12.93 \%$ of the amount and $29.78 \%$ of the amount, respectively). (1.09\% of the amount and $13.09 \%$ of the amount, respectively). These 
are cinnamyl acetate $(12.24 \%$ of the amount and $16.92 \%$ of the amount, respectively) and caryophyllene oxide (1.09\% of the amount and $13.09 \%$ of the amount, respectively).

\section{Discussion of research results}

For the first time a comparative analysis of the component composition of essential oil of 2 series of shoots and 2 series of leaves of Laurus nobilis L. of domestic harvest was carried out, general and distinctive features were revealed.

The high content of 1,8-cineole can cause antimicrobial, fungicidal and antiviral action, enhance the drainage function of the ciliated airway epithelium. Quite high content of sesquiterpene alcohol spatulenol type aromadendran can cause fungicidal action, triterpene alcohol of lupan row betulenol, and its derivatives show different types of biological activity - anti-inflammatory, activate collagen synthesis, inhibit elastase activity.

The advantage of the results of the study is the fact that this is one of the first steps in the study of several types of raw materials widely used in world medicine essential oil plant, whose raw materials are harvested in Ukraine and not yet standardized in pharmacy in our country. Certain disadvantages are the number of analyzed samples and varieties of plant raw materials (bark, flowers, fruits), which could be eliminated by further research.

Some difficulties in comparative analysis of the results with data from researchers from different countries are because sometimes the literature does not indicate the type of raw material at all, or does not indicate what is considered shoots (young leafy or isolated stems).

Thus, the quantitative content of essential oil from shoots of 2 series (shoots of series 1 contained $0.85 \pm 0.05 \%$, shoots of series $2-0.91 \pm 0.04 \%$ of essential oil) is comparable with the results obtained by researchers from Bulgaria shoots $-0.80 \%$ ) [9] and Montenegro (1.4\% in young shoots and $0.80 \%$ in isolated stems) [10]. At that time, the results of the quantitative content of essential oil in the leaves of 2 series (leaves of series 1 contained 2.15 $\pm 0.09 \%$, leaves of series $2-2.75 \pm 0.09 \%$ of essential oil) differ significantly from the results of Bulgarian (3.25\%) [9] and Montenegrin (1.5\%) researchers [10].

Comparing the results of determining the component composition of the essential oil series of Laurus nobilis L. shoots of Ukrainian origin, for example, with the essential oil of this raw material from Bulgaria, we can say that the percentage of $\alpha$-terpinyl acetate in two series of essential oil shoots of Ukrainian origin was higher $(16.22 \%$ of the amount and $16.03 \%$ of the amount, respectively) than in the essential oil of Bulgaria (13.1\% of the amount) [9]. It should be noted that the percentage of 1,8-cineole is much higher in the essential oil of raw materials of Bulgarian origin $(48.5 \%$ of the amount), which is almost 2.5 times higher than the percentage of this compound in the essential oil from Ukraine (19.63\% of amounts in 1 series).

For the two batches of the essential oil of the leaves, the common components were methyleugenol (7.14 \% of the amount and $7.57 \%$ of the amount, respectively), trans-methylisoeugenol $(5.7 \%$ of the amount and $0.65 \%$ of the amount) and sequiterpenoid caryophyllene oxide (13.09\% of the amount and 3.53 $\%$ of the amount). It should be noted that the content of methyleugenol and caryophyllene oxide in the essential oil of leaves of Laurus nobilis L. from Bulgaria is much lower $(6.03 \%$ of the amount and $0.34 \%$ of the amount, respectively) [9] than in the essential oil of this raw material of Ukrainian origin. In the essential oil of the leaves of the Egyptian harvest [17] the percentage of methyleugenol ( $7.67 \%$ of the amount) is comparable to this indicator of the essential oil of the leaves of the Ukrainian harvest in the absence of transmethylisoeugenol, and in the essential oil of raw materials harvested in Turkey, the percentage of methyleugenol $8 \%$ of the amount in the absence of transmethylisoeugenol and caryophyllene oxide [18].

Thus, the component composition of essential oils of shoots and leaves of Laurus nobilis L. of Ukrainian harvest is comparable to this indicator of raw materials of other countries of harvest.

A limitation of the study could be considered the volume of the library of mass spectra of compounds, which leads to the presence of unidentified compounds. In addition, the metrological evaluation of the measurement results was not performed because these studies are the first step towards the standardization of raw materials and are likely to have an indicative value in terms of the component composition of the raw material series. However, due to the high reproducibility and accuracy of the GC/MS method, these results can be taken into account in the further study of essential oils of shoots and leaves of Laurus nobilis L., in particular, artificial cultivation.

Promising areas for further research are similar studies of raw materials cultivated in artificial conditions Laurus nobilis L., which will improve the availability of raw materials and, of course, expand its boundaries. Also promising is further study of the chemical composition of shoots and leaves (especially phenolic compounds, in particular tannins) and phytotechnological research with the development of a dosage form in the form of a galenic drug or solid dosage form (capsules, tablets).

\section{Conclusion}

The component composition of essential oil of 4 samples of raw material Laurus nobilis L. (2 series of shoots and 2 series of leaves) was investigated and established.

The composition of compounds that are distilled with water vapour, a series of shoots is similar both in the set of components and in the relative content of a number of individual compounds and structurally related groups of compounds. Thus, in the shoots of Laurus nobilis L. series 1 were identified 36 essential oil, and in series $2-30$ components. 10 compounds (of which 1 is unidentified) are characteristic of the essential oil of shoots of series 1 , and 4 - is contained only in series 2 .

The component composition of the essential oil of the leaves of the two studied series differed significantly in the set of components and their relative content. This may indicate that the accumulation of a number of substances in the same type of raw material depends on the location and conditions of plant growth. In both series, only 3 com- 
pounds were invented, which are common - the aromatic compounds methyleugenol, trans-methylisoeugenol and the sequiterpenoid caryophyllene oxide.

Comparative analysis of the component composition of biologically active substances in the essential oil of shoots and leaves of Laurus nobilis L. showed the prospects for further pharmacognostic study of this plant as a source of medicinal raw materials.

\section{Conflict of interests.} interest

\section{Financing}

The study was performed as part of a comprehensive research work of the National University of Pharmacy "Pharmacognostic study of medicinal plant raw materials and development of phytotherapeutic agents based on it" (state registration number 0114U000946).

\section{Acknowledgements}

We express our deep gratitude to the associate professor of the Department of Botany of NUPh Rudenko V. P. for the botanical determination of the plant, the raw material of which we studied.

\section{References}

1. Laurel noble (Laurus nobilis). Available at: https://lektrava.ru/encyclopedia/lavr-blagorodnyy/

2. Barroso, W., Duarte Gondim, R., Marques, V., Lael, M., Santos, P., Oliveira Castro, A. et. al. (2018). Pharmacognostic Characterization of Laurus nobilis L. Leaves. Journal of Chemical and Pharmaceutical Research, 10 (1), 30-37. Available at: https://www.jocpr.com/archive/jocpr-volume-10-issue-1-year-2018.html

3. Basak, S. S., Candan, F. (2013). Effect of Laurus nobilis L. Essential Oil and its Main Components on $\alpha$-glucosidase and Reactive Oxygen Species Scavenging Activity. Iranian journal of pharmaceutical research, 12 (2), 367-379. Available at: http://www.ncbi.nlm.nih.gov/pmc/articles/PMC3813252

4. Muñiz-Márquez, D. B., Wong-Paz, J. E., Contreras-Esquivel, J. C., Rodríguez-Herrera, R., Aguilar, C. N. (2018). Bioactive compounds from bay leaves (Laurus nobilis) extracted by microwave technology. Zeitschrift Für Naturforschung C, 73 (9-10), 401-407. doi: http://doi.org/10.1515/znc-2018-0009

5. Mansour, O., Darwish, M., Ismail, G., Douba, Z., Ismaeel, A., Eldair, K. (2018). Review Study on the Physiological Properties and Chemical Composition of the Laurus nobilis. The Pharmaceutical and Chemical Journal, 5 (1), 225-231. Available at: https://www.researchgate.net/publication/323883941_Review_Study_on_the_Physiological_Properties_and_Chemical_Composition_of_ the_Laurus_nobilis

6. Bayramoglu, B., Sahin, S., Sumnu, G. (2009). Extraction of Essential Oil from Laurel Leaves by Using Microwaves. Separation Science and Technology, 44 (3), 722-733. doi: http://doi.org/10.1080/01496390802437271

7. Furtado, R., Baptista, J., Lima, E., Paiva, L., Barroso, J. G., Rosa, J. S., Oliveira, L. (2014). Chemical composition and biological activities of Laurus essential oils from different Macaronesian Islands. Biochemical Systematics and Ecology, 55, $333-341$. doi: http://doi.org/10.1016/j.bse.2014.04.004

8. Boughendjioua, H. (2017). Effective antifungal and antioxidant properties of essential oil extracted from the leaves of Laurus nobilis L. wild-growing in Algeria. International Journal of Biosciences, 11 (4), 164-172. Available at: http://doi.org/10.12692/ijb/11.4.164-172

9. Fidan, H., Stefanova, G., Kostova, I., Stankov, S., Damyanova, S., Stoyanova, A., Zheljazkov, V. D. (2019). Chemical Composition and Antimicrobial Activityof Laurus nobilis L. Essential Oils from Bulgaria. Molecules, 24 (4), 804. doi: http://doi.org/10.3390/ molecules 24040804

10. Kovacevic, N. N., Simic, M. D., Ristic, M. S. (2007). Essential oil of Laurus nobilis from Montenegro. Chemistry of Natural Compounds, 43 (4), 408-411. doi: http://doi.org/10.1007/s10600-007-0150-x

11. Caputo, L., Nazzaro, F., Souza, L., Aliberti, L., De Martino, L., Fratianni, F. et. al. (2017). Laurus nobilis: Composition of Essential Oil and Its Biological Activities. Molecules, 22 (6), 930. doi: http://doi.org/10.3390/molecules22060930

12. Bhouri, N., Debbabi, F., Ben Salem, I., Ben Abdessalem, S. (2018). Exploitation of essential oil extracted from TunisianLaurus nobilisfor the development of PET antibacterial sutures. The Journal of The Textile Institute, 109 (10), 1282-1292. doi: http://doi.org/10.1080/00405000.2017.1423006

13. Marques, A., Teixeira, B., Nunes, M. L. (2016). Bay Laurel (Laurus nobilis) Oils. Essential Oils in Food Preservation, Flavor and Safety, 239-246. doi: http://doi.org/10.1016/b978-0-12-416641-7.00026-2

14. Kaur, M., Chahal, K., Kumar, A., Kaur, R. (2018). Nematicidal activity of bay leaf (Laurus nobilis L.) essential oil and its components against. Meloidogyne incognita. Journal of Entomology and Zoology Studies, 6 (2), 1057-1064. Available at: https://www.semanticscholar.org/paper/Nematicidal-activity-of-bay-leaf-(Laurus-nobilis-Kaur-

hahal/5dfc8d9147215198bcc8417489b91ff77f92a9f2

15. Fonseca, B., Mestre, V. F., Colaço, B., Pires, M., Martins, T., Gil da Costa, R. et. al. (2018). Laurus nobilis (laurel) aqueous leaf extract's toxicological and anti-tumor activities in HPV16-transgenic mice. Food \& Function, 9, 4419-4428. doi: http://doi.org/10.1039/c8fo00783g

16. Kivçak, B., Mert, T. (2002). Preliminary evaluation of cytotoxic properties of Laurus nobilis leaf extracts. Fitoterapia, 73 (3), 242-243. doi: http://doi.org/10.1016/s0367-326x(02)00060-6

17. Siriken, B., Yavuz, C., Guler, A. (2018). Antibacterial Activity of Laurus nobilis: A review of literature. Medical Science and Discovery, 5 (11), 374-379. doi: http://doi.org/10.17546/msd.482929

18. Fernandez, C. M. M., da Rosa, M. F., Fernandez, A. C. A. M., Lorenzetti, F. B., Raimundo, K. F., Cortez, D. A. G. et. al. (2018). Larvicidal activity against Aedes aegypti of essential oil of Laurus nobilis leaves obtained at different seasons. Journal of Essential Oil Research, 30 (5), 379-387. doi: http://doi.org/10.1080/10412905.2018.1473294 
19. Tabanca, N., Avonto, C., Wang, M., Parcher, J. F., Ali, A., Demirci, B. et. al. (2013). Comparative Investigation of Umbellularia californica and Laurus nobilis Leaf Essential Oils and Identification of Constituents Active against Aedes aegypti. Journal of Agricultural and Food Chemistry, 61 (50), 12283-12291. doi: http://doi.org/10.1021/jf4052682

20. Kyslychenko, A., Dyakonova, Ya., Alexandrov, A., Darmogray, R. (2008). Gas chromatography with mass-spectrometric detection of the components of the essential oils from Achillea carpatica Blocki ex Dubovik and Echinaceae pallida (Nutt.) Herba Polonica Journal, 54 (4), 62-67. Available at: http://www.herbapolonica.pl/articles/view/38

Received date 06.07.2021

Accepted date 24.08.2021

Published date 31.08.2021

Olga Khvorost*, Doctor of Pharmacy, Professor, Department of Chemistry of Natural Compounds and Nutrition, National University of Pharmacy, Pushkinska str., 53, Kharkiv, Ukraine, 61002

Irina Posohova, Postgraduate Student, Department of Chemistry of Natural Compounds and Nutrition, National University of Pharmacy, Pushkinska str., 53, Kharkiv, Ukraine, 61002

Yuliia Fedchenkova, Doctor of Pharmacy, Professor, Department of Chemistry and Pharmacy, Nizhyn Mykola Gogol State University, Grafska str., 2, Nizhyn, Chernihiv Region, Ukraine, 16600

Kateryna Skrebtsova, $\mathrm{PhD}$, Assistant Department of Chemistry of Natural Compounds and Nutrition, National University of Pharmacy, Pushkinska str., 53, Kharkiv, Ukraine, 61002

*Corresponding author: Olga Khvorost, e-mail: khvorost09101960@gmail.com 